\title{
A Rapid Fluorometric Assay of Angiotensin-Converting Enzyme
}

\author{
Makoto Hayakari and Yoshikazu Kondo \\ Pharmaceutical Institute, Tohoku University, Aobayama, \\ Sendai 980
}

Hayakari, M. and Kondo, Y. A Rapid Fluorometric Assay of AngiotensinConverting Enzyme. Tohoku J. exp. Med., 1977, 122 (4), 313-320—A rapid, simple and sensitive method is described for the fluorometric assay of angiotensin. converting enzyme using Fluorescamine. The critical factors such as optimal $\mathrm{pH}$, incubation time, chloride ion, and inactivation by EDTA and 8 -hydroxyquinoline were examined. The $\mathrm{Km}$ value for hippuryl-L-histidyl-L-leucine was $0.5 \mathrm{mM}$. This method was applied to the assay of angiotensin-converting enzyme in the rat serum and the reproducible values were obtained with a $10 \mu \mathrm{l}$ of the rat serum.

angiotensin-converting enzyme; angiotensin I; angiotensin II ; Fluorescamine

Angiotensin-converting enzyme, which converts angiotensin I to angiotensin II, is a widely occurring enzyme in animal organs. In principle, the most suitable method for determination of this enzyme activity involves the use of the artificial substrate, hippuryl-L-histidyl-L-leucine (HHL) or hippuryl-glycyl-glycine, and determination of the consequently released substances. Piquillord et al. (1970) have reported a method in which L-histidyl-L-leucine released from artificial substrates by the enzymic hydrolysis was assayed fluorometrically using ophthalaldehyde. Cushman and Cheung (1971b) have employed the other method for the assay of angiotensin-converting enzyme in which hippuric acid released from HHL was determined spectrophotometrically. We also developed a rapid and simple spectrophotometric method of assay of angiotensin-converting enzyme by using 2,4,6-trichloro-s-triazine as a colorimetric reagent (Hayakari et al. 1977).

Weigel et al. (1972) developed Fluorescamine which forms the fluorescent substance by reacting with primary amines, and Böhlen et al. (1973) and Nakamura and Pisano (1976 a, b) reported its application for the detection of amino acids, peptides and proteins.

In this paper, we describe a rapid, simple and sensitive fluorometric assay of angiotensin-converting enzyme, partially purified from hog lung, and in addition, its application to the assay of the serum enzyme activity. Fluorescamine is well suited for this purpose since it easily forms a sensitive fluorescent compound with released L-histidyl-L-leucine. The fluorescent compound is analyzed quantitatively and reproducibly.

Received for publication, January 31, 1977. 


\section{Materials and Methods}

HHL and L-histidyl-L-leucine were obtained from Protein Research Foundation, Osaka. Fluorescamine was obtained from Hoffmann-La Roche. Dioxan (analytical reagent grade, redistilled prior to use) and Triton $\mathrm{X}$-100 were purchased from Nakarai Chemicals, Kyoto. EDTA was from Kokusan Chemicals Works, Tokyo. 8-Hydroxyquinoline was from Wako Chemicals, Osaka, and was used without further purification. DEAE-cellulose and Sephdaex G-150 were from Seigagaku Kogyo, Tokyo. DEAEcellulose was treated with $0.5 \mathrm{~N} \mathrm{HCl}$ and $0.5 \mathrm{~N} \mathrm{NaOH}$ before equilibration in $10 \mathrm{mM}$ potassium phosphate buffer, $\mathrm{pH} \mathbf{7 . 2}$.

Preparation of angiotensin-converting enzyme from hog lung. Angiotensin-converting enzyme was partially purified from hog lung by a modification of the method of Soffer et al. (1974). The hog lung was homogenized in cold $10 \mathrm{mM}$ potassium phosphate buffer, $\mathrm{pH}$ 7.2 , using Waring blender and filtered through two layers of cheese-cloth. The filtrate was centrifuged at $1,000 \times \mathrm{g}$ for $20 \mathrm{~min}$ and the supernatant obtained was recentrifuged at $75,000 \times \mathrm{g}$ for $90 \mathrm{~min}$. The pellet was suspended in cold $10 \mathrm{mM}$ potassium phosphate buffer, $\mathrm{pH} 7.2$, and a $10 \%$ solution (by vol.) of Triton $\mathrm{X}-100$ was added to a final concentration of $0.1 \%$. The suspension was then stirred at $4^{\circ}$ for $45 \mathrm{~min}$, and centrifuged at $105,000 \times \mathrm{g}$ for $10 \mathrm{~min}$. The supernatant was dialyzed overnight against 5 liters of $10 \mathrm{mM}$ potassium phosphate buffer, $\mathrm{pH} 7.2$.

$D E A E$-cellulose chromstography. The dialyzed supernatant solution was applied on a DEAE-cellulose column $(1.8 \times 45 \mathrm{~cm})$ previously equilibrated with $10 \mathrm{mM}$ potassium phosphate buffer, $\mathrm{pH} 7.2$. The column was eluted with a $0-0.5 \mathrm{M}$ linear $\mathrm{NaCl}$ gradient, and $10 \mathrm{ml}$ fractions were collected. The active fractions were combined and lyophilized to dryness.

Gel filtration on Sephadex G-150. The lyophilized residue was chromatographed on a column $(1.8 \times 45 \mathrm{~cm})$ of Sephadex G-150 equilibrated with $10 \mathrm{mM}$ potassium phosphate buffer, $\mathrm{pH} 8.0$, and $5 \mathrm{ml}$ fractions were collected. The active fractions were combined and stocked as the enyzme sourse.

Serum samples. Spraugue-Dawley male rats (CLEA, Japan Inc.) weighing $250 \mathrm{~g}$ were used in these experiments. After the animals were decapitated, blood was collected in a clean tube containing sodium citrate and centrifuged at $700 \times \mathrm{g}$ for $10 \mathrm{~min}$. The supernatant was used as an enzyme sample.

Fluorometric assay of angiotensin-converting enzyme. The assay for the angiotensinconverting enzyme activity was carried out in a $0.5 \mathrm{ml}$ incubation mixture containing 40 $\mu$ moles potassium phosphate buffer ( $\mathrm{pH} 8.3$ ), $300 \mu$ moles sodium chloride, $1.5 \mu$ moles HHL, and the enzyme. The reaction was initiated by the addition of the substrate and the reaction mixture was incubated at $37^{\circ}$ for $15 \mathrm{~min}$. The reaction was stopped by placing the incubation mixture in boiling water bath for $10 \mathrm{~min}$, them $2.5 \mathrm{ml}$ of $0.2 \mathrm{M}$ potassium

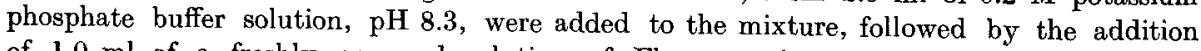
of $1.0 \mathrm{ml}$ of a freshly prepared solution of Fluorescamine $(0.3 \mathrm{mg}$ per ml) in dioxan with vigorous stirring. The fluorescence was monitored at $480 \mathrm{~nm}$ with the excitation at $380 \mathrm{~nm}$. All fluorescence measurements were made with a Shimazu GF-16 spectrofluorometer.

Protein concentration. Protein concentrations were determined by a modification of the method of Lowry et al. (1951).

\section{Results}

Identification of $L$-histidyl-L-leucine as a released product by action of the angiotensinconverting enzyme

In order to determine the specificity of the enzyme to the artificial substrate, 
HHL, the released substances in the incubation mixture were investigated by a modification of the method of Piquillord et al. (1970). To $0.25 \mathrm{ml}$ of the converting enzyme $(0.3 \mathrm{mg}$ protein $/ \mathrm{ml})$ was added $1 \mathrm{ml}$ of $0.2 \mathrm{M}$ potassium phosphate buffer, $\mathrm{pH} 8.3$, and $1.0 \mathrm{ml}$ of $1.5 \mathrm{M} \mathrm{NaCl}$, and the reaction was started by the addition of $0.25 \mathrm{ml}$ of $30 \mathrm{mM}$ HHL. After being held at $37^{\circ}$ for $15 \mathrm{~min}$, the reaction was terminated by adding $2 \mathrm{ml}$ of ethanol to bring the final volume of the reaction mixture to $2.5 \mathrm{ml}$, which was five times of the standard scale. The mixtue was centrifuged and the supernatant was evaporated to dryness in vacuo. The residue was dissolved in a small volume of methanol and applied to a thin layer plate of Silica gel G. The chromatography was carried out using n-butanol-acetic acidwater (12:3:5, by vol.) as the developing solvent. The plate was sprayed with Fluorescamine solution to detect L-histidyl-L-leucine (Rf, 0.23) as a blue spot. Unhydrolysed substrate ( $\mathrm{Rf}, 0.47$ ) showed a strong ultraviolet light absorption but no fluorescence. Neither L-histidine nor L-leucine was detected.

Calibration curve. A $0.2 \mathrm{mM}$ solution of the dipeptide L-histidyl-L-leucine was used to prepare a calibration curve. $1,5,10,25,50$ and 100 nmoles were exactly pipetted into triplicated series of test tubes. To each tube was added successibly $2.5 \mathrm{ml}$ of $0.2 \mathrm{M}$ potassium phosphate buffer, $\mathrm{pH} 8.3$, and $1 \mathrm{ml}$ of Fluorescamine solution $(0.3 \mathrm{mg} / \mathrm{ml})$ in dioxan with vigorous stirring and the fluorescence was measured at $480 \mathrm{~nm}$ with the excitation at $380 \mathrm{~nm}$. Fig. 1 shows a typical calibration curve for the assay which gave linear relationship.

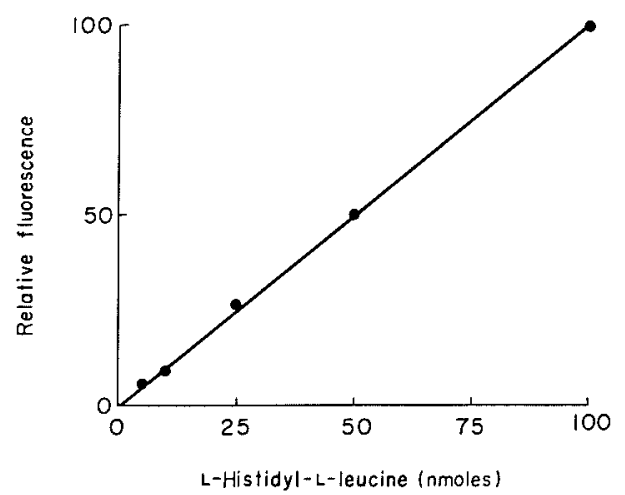

Fig. 1. Calibration curve for L-histidyl-L-leucine quantity verus relative fluorescence.

\section{Effect of conditions of the incubation}

Incubation time. The reaction proceeded linearly for $30 \mathrm{~min}$ with either of three different amounts of the enzyme as shown in Fig. 2.

Enzyme concentration. The concentration of enzyme was expressed as milligrams of protein in the applied enzyme preparation. The enzyme activity was proportional to the amount of enzyme as shown in Fig. 3.

$p H$. The activity of enzyme increased with $\mathrm{pH}$, reaching a maximum at $\mathrm{pH}$ 


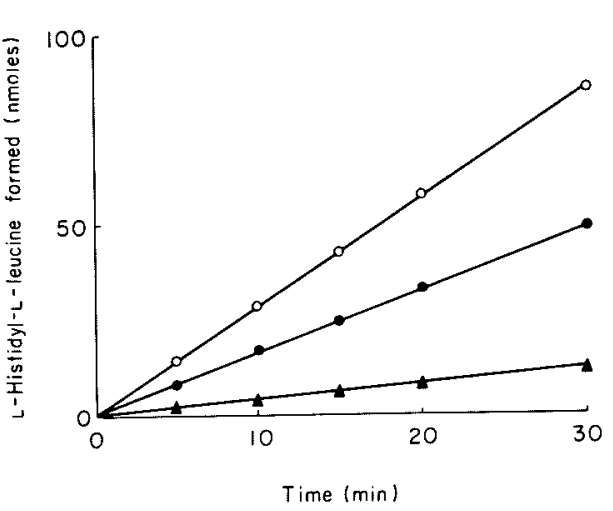

Fig. 2

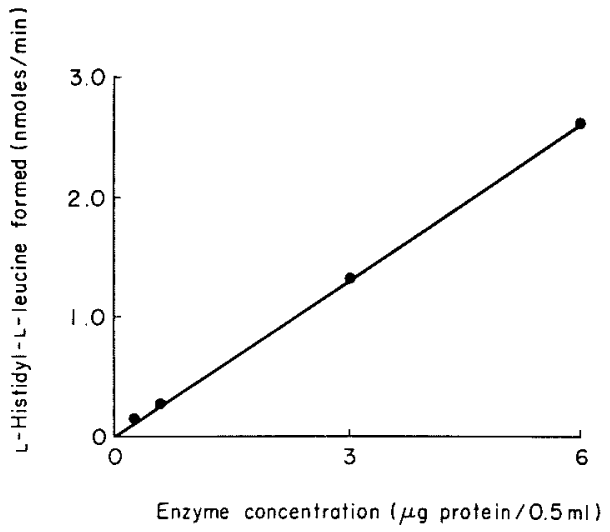

Fig. 3

Fig. 2. Time course of the reaction with partially purified hog lung enzyme. Enzyme concentrations: $0,6 \mu \mathrm{g}$ protein per assay; $\bullet, 3 \mu \mathrm{g}$ protein per assay; $\Delta, 0.6 \mu \mathrm{g}$ protein per assay.

Fig. 3. Hydrolysis of HHL as a function of concentration of partially purified hog lung enzyme. Incubation conditions were as described for the standard assay.

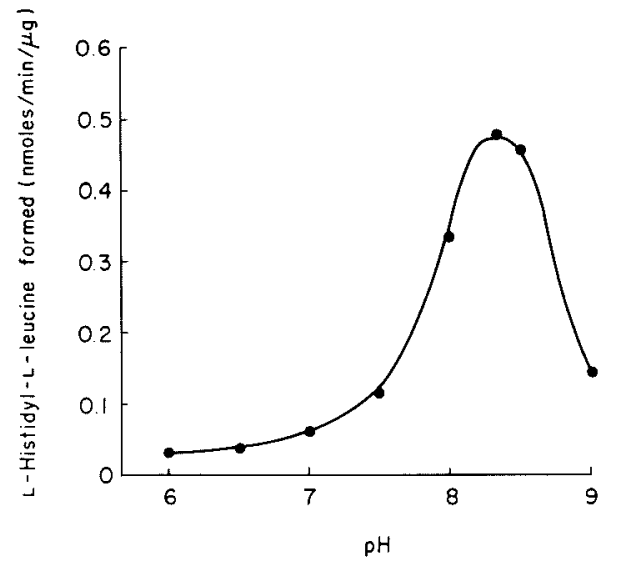

Fig. 4

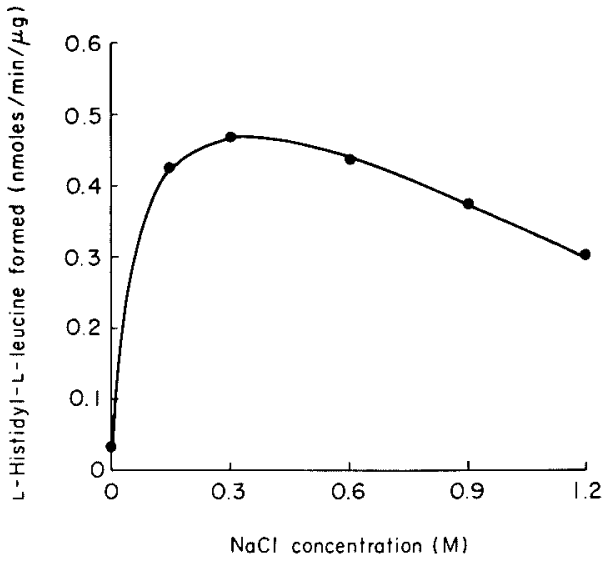

Fig. 5

Fig. 4. Effect of $\mathrm{pH}$ on the activity of partially purified hog lung enzyme. Assay conditions were as described in Methods. The buffer used was $0.2 \mathrm{M}$ potassium phosphate buffer and enzyme ( $3 \mu \mathrm{g}$ protein per tube) was incubated at $37^{\circ}$ for $15 \mathrm{~min}$ in the presence of $0.3 \mathrm{M} \mathrm{NaCl}$.

Fig. 5. Effect of chloride ion on the activity of partially purified hog lung enzyme. Enzyme (3 $\mu \mathrm{g}$ protein per tubes) was incubated at $37^{\circ}$ for $15 \mathrm{~min}$ under conditions described in Methods without $0.3 \mathrm{M} \mathrm{NaCl}$.

8.0-8.5 in the presence of $0.3 \mathrm{M} \mathrm{NaCl}$ (Fig. 4). $\mathrm{pH} 8.3$ was chosen for the standard assay system.

Chloride ion. The chloride ion is an obligatory requirement for the activity of angiotensin-converting enzyme, and the optimal concentration of sodium chloride for the reaction was found to be 150 to $600 \mathrm{mM}$, as shown in Fig. 5 . 


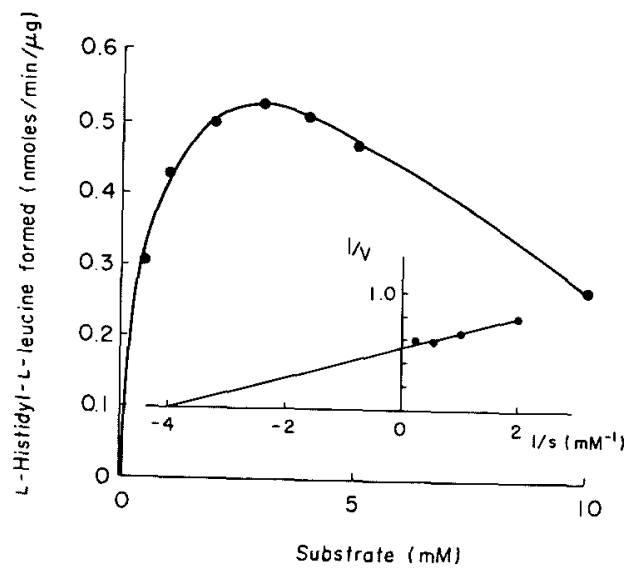

Fig. 6. Effect of varing concentrations of substrate on the activity of partially purified hog lung enzyme. Assay conditions were as described in Methods. Reactions were started by the addition of varous concentrations of HHL and the incubation was carried out at $37^{\circ}$ for $15 \mathrm{~min}$. $V$, reaction velocity as nmoles $/ \mathrm{min}$; $\mathrm{S}$, substrate concentration as $\mathrm{mM}$.

TABLE 1. Inhibition of partially purified angiotensin-converting enzyme of hog lung by the chelating reagents

\begin{tabular}{ccc}
\hline Compound & Concentration $(M)$ & $\%$ of control activity \\
\hline EDTA & $1 \times 10^{-3}$ & 18 \\
& $1 \times 10^{-4}$ & 25 \\
& $1 \times 10^{-5}$ & 36 \\
8.Hydroxy- & $1 \times 10^{-3}$ & 49 \\
quinoline & $1 \times 10^{-4}$ & 98 \\
& $1 \times 10^{-5}$ & 100 \\
\hline
\end{tabular}

The enzyme (3 $\mu \mathrm{g}$ protein) was incubated for $15 \mathrm{~min}$ at $37^{\circ} \mathrm{C}$ under coditions as described in Methods.

Substrate concentration. The apparent $\mathrm{Km}$ value for $\mathrm{HHL}$ was calculated to be approximately $0.5 \mathrm{mM}$ (Fig. 6).

Inhibition by EDTA and 8-hydroxyquinoline. As seen in Table 1, both EDTA and 8-hydroxyquinoline at a concentration of $1 \mathrm{mM}$ significantly inhibited the enzyme. Especially, EDTA was inhibitory even at as low as $0.1 \mathrm{mM}$.

Amount of serum. The angiotensin-converting activity of rat serum increased linearly with the increase in the amount of serum employed (Fig. 7).

\section{Discussion}

The precise determination of the angiotesin-converting enzyme activity in serum has provided ancillary information regarding clinical diagnosis of sarcoidosis and Gaucher's disease (Lieberman et al. 1975, 1976; Silberstein et al. 1975, 1976). Patients with clinical sarcoidosis and Gaucher's disease exhibit an elevated level 


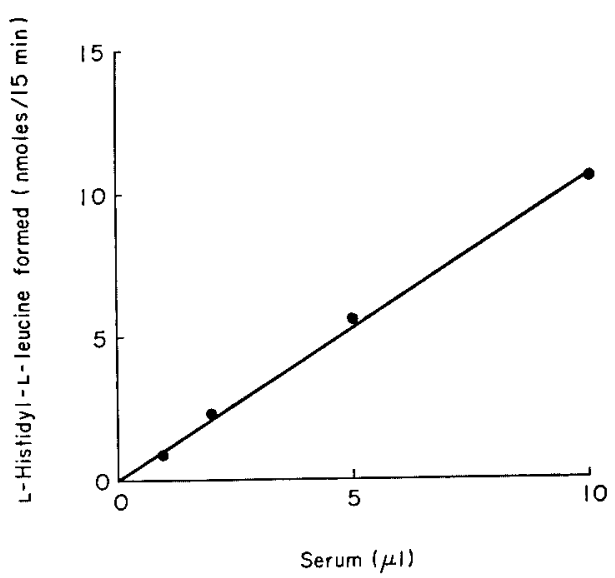

Fig. 7. Relationship between the amount of the serum angiotensin-converting enzyme and the rate of release of L-histidyl-L-leucine. Reaction was carried out in a $0.5 \mathrm{ml}$ incubation mixture containing $40 \mu$ moles potassium phosphate buffer, $\mathrm{pH} 8.3,300 \mu$ moles sodium chloride and $1.5 \mu$ moles HHL. Blank values were examined at respective serum concentrations to cancel any influence of serum on fluorescence intensity.

of angiotensin-converting enzyme activity in the serum, and on this basis these patients are readily distinguished from others with lung cancer or other lung diseases. One method for determining serum levels of angiotensin-converting enzyme involves the use of the artificial substrate, HHL or hippuryl-glycyl-glycine. These artificial substrates are hydrolysed to hippuric acid plus L-histidyl-L-leucine or hippuric acid plus glycyl-glycine by the enzymic reaction. In principle, the routine assay method of the enzyme levels is based on the determination of a released component, either hippuric acid or the dipeptide. We have recently developed a rapid and simple spectrophotometric method of assay of this enzyme, in which 2,4,6trichloro-s-triazine is employed as a colorimetric reagent for the spectrophotometric determination of hippuric acid (Hayakari et al. 1977).

In the present investigation, Fluorescamine was used for the fluorometric assay of the released L-histidyl-L-leucine. In this study we used the angiotensinconverting enzyme partially purified from hog lung rather than the serum enzyme because the enzyme concentration is higher in the lung than in serum (Cushman and Cheung. 1971a).

A number of experimental investigations have revealed that the pulmonary enzyme, which converts HHL to hippuric acid plus L-histidyl-L-leucine, is identical with the angiotensin-converting enzyme and has specific properties (Fitz et al. 1971). Our data indicated that the partially purified lung enzyme was equally efficacious for the artificial substrate, $\mathrm{HHL}$, and had comparable specific properties as those of the serum enzyme. Furthermore, the release of histidine or leucine during the incubation could not be detected by means of the thin layer chromatography. In consequence, there is no doubt that the pulmonary enzyme purified from hog lung is the angiotensin-converting enzyme. There are a number of critical factors in this 
enzymic reaction; the incubation time, the enzyme concentration, the $\mathrm{pH}$ value and the chloride ion concentration (Fig. 2-5), which are in agreement with the findings of Cushman and Cheung (1971b). The enzymic reaction was interfered with the presence of the chelating reagent such as EDTA and 8-hydroxyquinoline.

We have examined the activity of the serum angiotensin-converting enzyme in the rat using this method. The assay, which requires only $10 \mu 1$ of rat serum at the most and as the most suitable amount, can measure the activity of angiotensinconverting enzyme within $15 \mathrm{~min}$ (Fig. 7). Under the conditions employed, this method gave reproducible values of the enzyme activity quickly. In addition, the sensitivity of the assay can be enhanced approximately 2 -fold by heating of the incubation mixture in strong acid (Nakamura and Pisano 1976c). Duplicate assays of the fresh serum and the serum dialzyed against buffer for $24 \mathrm{hr}$ before assay showed good agreement within the experimental error. Significant discrepancies occurred when over $20 \mu \mathrm{l}$ of serum were used. Biogenic amines and amino acids in serum are probably attributable to this discrepancies. More recently, Friedland and Silberstein (1976) also measured the human serum angiotensinconverting enzyme activity fluorometrically using $o$-phthalaldehyde as a fluorometric reagent. However, o-phthalaldehyde forms a fluorescent substance with ammonia and hence the substance formed interferes with the fluorometric measurement of the enzyme activity. On the other hand, the assay with Fluorescamine is not affected by ammonia.

\section{References}

1) Böhlen, P., Stein, S., Dairman, W. \& Udenfriend, S. (1973) Fluorometric assay of proteins in the nanogram range. Arch. Biochem. Biophys., 155, 213-220.

2) Cushman, D.W. \& Cheung, H.S. (1971 a) Concentrations of angiotensin-converting enzyme in tissues of the rat. Biochim. biophys. Acta (Amst.), 250, 261-265.

3) Cushman, D.W. \& Cheung, H.S. (1971 b) Spectrophotometric assay and properties of the angiotensin-converting enzyme. Biochem. Pharmac., 20, 1637-1648.

4) Fitz, A., Boyd, G.W. \& Peart, S. (1971) Converting enzyme activity in human plasma. Circulat. Res., 28, 246-253.

5) Friedland, J. \& Silberstein, E. (1976) A sensitive fluorometric assay for serum angiotensin-converting enzyme. Amer. J. clin. Path., 66, 416-424.

6) Hayakari, M., Kondo, Y. \& Izumi, H. (1977) A Rapid and simple spectrophotometric assay of angiotensin-converting enzyme. Anal. Biochem., in press.

7) Lieberman, J. (1975) Elevation of serum angiotensin-converting enzyme (ACE) level in sarcoidosis. Amer. J. Med., 59, 356-372.

8) Lieberman, J. (1976) Elevation of serum angiotensin-converting enzyme in Gaucher's disease. New Engl. J. Med., 294, 1442-1444.

9) Lowry, O.H., Rosebrough, N.J., Farr, A.L. \& Randall, R.J. (1951) Protein measurement with the folin phenol reagent. J. biol. Chem., 193, 265-275.

10) Nakamura, H. \& Pisano, J.J. (1976 a) Reaction of tryptophan, tryptamines, and some related indoles with fluorescamine: unique fluorescence in strong acid. Arch. Biochem. Biophys., 172, 98-101.

11) Nakamura, H. \& Pisano, J.J. (1976 b) Sensitive fluorometric assay for proteins: use of fluorescamine and membrane filters. Arch. Biochem. Biophys., 172, 102-105.

12) Nakamura, H. \& Pisano, J.J. (1976 c) Fluorescamine derivatives of histidine, histamine, and certain related imidazoles: unique fluorescence after heating in acid. Arch. 
Biochem. Biophys., 177, 334-335.

13) Piquillord, Y., Reinharz, A. \& Roth, M. (1970) Studies on the angiotensin-converting enzyme with different substrate. Biochim. biophys. Acta (Amst.), 206, 136-142.

14) Silberstein, E., Friedland, J., Lyons, H.A. \& Gourin, A. (1975) Serum angiotensinconverting enzyme in sarcoidosis. Clin. Res., 23, 352A.

15) Silberstein, E., Friedland, J., Lyons, H.A. \& Gourin, A. (1976) Markedly elevated angiotensin-converting enzyme in lymph nodes containing non-nesrotizing granulomas in sarcoidosis. Proc. nat. Acad. Sci. USA, 73, 2137-2141.

16) Soffer, R.L., Reza, R. \& Caldwell, P.R.B. (1974) Angiotensin-converting enzyme from pulmonary particles. Proc. nat. Acad. Sci. USA, 71, 1720-1724.

17) Weigel, M., Blount, J.F., Tengi, J.P., Czaikowsky, R.C. \& Leingruber, W. (1972) The fluorogenic ninhydrin reaction. Structure of the fluorescent principle. $J$. Amer. Chem. Soc., 94, 4052-4054. 